\title{
SLAUGYTOJŲ DARBO APLINKOS RIZIKOS VEIKSNIŲ IR PASITENKINIMO GYVENIMO KOKYBE SĄSAJOS
}

\author{
Raimonda Jonikaitè ${ }^{1}$ Indrė Brasaitè ${ }^{2}$ \\ ${ }^{1}$ Klaipédos jūrininku ligoniné, ${ }^{2}$ Klaipédos universiteto Sveikatos mokslu fakultetas
}

Raktažodžiai: slaugytojas, pasitenkinimas gyvenimu, darbo aplinkos rizikos veiksniai.

\begin{abstract}
Santrauka
Slaugytojai savo darbe susiduria su neigiamą ịtaką jų sveikatai, darbingumui ir fizinei būklei darančiais veiksniais: dideliu fizinio darbu krūviu, budejjimu naktimis, psichologiniu smurtu, organizaciniais darbų trūkumais, darbo pareigų stresoriais. Nuo šių veiksnių priklauso pasitenkinimas gyvenimu ir darbu, kurie lemia kokybišką pacientų priežiūrą bei saugą, darbuotojų išsaugojimą organizacijoje ir jų ịsipareigojimą organizacijai bei profesijai.

Tiriamają imtị sudare 69 intensyvios terapijos ir chirurgijos skyrių slaugytojai, dirbantys Klaipedos ligoninèse. Tyrimas atliktas laikantis etikos principų. Atliktas kiekybinis tyrimas. Apklausai naudotas $\mathrm{Pa}-$ sitenkinimo gyvenimu klausimynas - trumpa forma. Gauti duomenys apdoroti SPSS programa (22 versija).

Tyrimo rezultatai parodè, kad dažniausi slaugytojų darbo aplinkos rizikos veiksniai yra intensyvus darbas ir pacientų kèlimas rankomis. Slaugytojai savo pasitenkinimą gyvenimu ịvertino geriau nei vidutiniškai. Vertinimo vidurkis buvo 66,8 proc. balų iš 100 proc. maksimaliai galimų. Gauti tyrimo rezultatai parodè, kad slaugytojų, kuriems dažniau tenka kelti pacientus rankomis, pasitenkinimas gyvenimu yra prastesnis.
\end{abstract}

\section{Ivadas}

Daugumai žmonių darbas yra svarbiausias veiksnys, apibūdinantis gyvenimo kokybę, gerovę, padedantis patenkinti beveik visus jo poreikius: saviraiškos, saugumo, socialinius, fiziologinius. Žmogaus pasitenkinimas darbu yra svarbi gyvenimo dalis, todèl tai veikia bendrą žmogaus pasitenkinimą gyvenimu [16].

Darbuotojų pasitenkinimas gyvenimu yra svarbus gyvenimo aspektas. Organizacijos koncentruojasi ne vien i susijusius su darbu aspektus, bet ir stengiasi kelti darbuotojų gerovę, gerinti darbinę aplinką, nes tai teikia naudą organizacijai, gerina darbo rezultatus, pritraukia ir leidžia išlaikyti darbuotojus [21].

Slaugytojai dèl savo veiklos pobūdžio sudaro ypatingą kontingentą, kuriam būdingi neigiamą ịtaką sveikatai, darbingumui ir fizinei būklei turintys veiksniai: didelis fizinio darbo krūvis, budejimas naktimis, kenksminga darbo aplinka [15]. Ivairių autorių nuomone [12, 8, 20, 23, 27, 28], fizikiniai, cheminiai, biologiniai, ergonominiai, psichologiniai darbo aplinkos veiksniai turi įtakos psichinei ir fizinei medicinos personalo sveikatai. Pagerinus darbo aplinką mažeja „,perdegimo“ dažnis, didejja darbo našumas [4], sumažèja pravaikštų, darbuotojų kaita, nepageidaujamų ịvykių darbe, didejja pasitenkinimas kitais gyvenimo aspektais $[5-7,13]$. Geros darbo sąlygos turi teigiamą poveikị ir asmeniniam dirbančių žmonių gyvenimui. Gerą emocinę savijautą ir fizinę energiją darbuotojai "nešasi" ị namus, todèl teigiama įtaka jaučiama ir asmeniniame gyvenime $[2,24]$.

Pasitenkinimas gyvenimu mokslininkų buvo tyrinèjamas 2013 metais [18]. Tirti Lietuvos restruktūrizuojamose ligoninèse dirbantys, ne mažesnę nei vienerių metų darbo patirtị turintys slaugytojai [18]. Tyrimų, vertinančių ịvairių populiacijos grupių pasitenkinimą gyvenimu, yra nemažai, tačiau nepavyko rasti tyrimų, kuriuose būtų nagrinèjama darbo įtaka slaugytojų pasitenkinimui gyvenimu.

Slaugytojų darbo aplinka nėra visiškai saugi. Galima prognozuoti, jog sunkumai, su kuriais susiduriama darbe, itempti santykiai su kolegomis ar pacientais, didelis darbo krūvis, kintantis darbo grafikas neigiamai veikia ne tik atliekamo darbo rodiklius, daugejja klaidingų sprendimų, mažèja gebejjimas kokybiškai ir laiku atlikti savo darbo užduotis, bet ir turi itakos pasitenkinimui gyvenimu. Šiame darbe keliama prielaida, kad darbo aplinkos rizikos veiksniai yra susiję su slaugytojų pasitenkinimu gyvenimu.

Tyrimo tikslas: nustatyti slaugytojų darbo aplinkos ri- 
zikos veiksnių ir pasitenkinimo gyvenimo kokybe sąsajas.

\section{Tyrimo medžiaga ir metodai}

Duomenys tyrimui buvo renkami naudojant klausimyną (Quality of Life Enjoyment and Satisfaction Questionnaire - Short Form (Q-LES-QSF)), JAV, Jean Endicott) [10]. Slaugytojų apklausa vyko $2015 \mathrm{~m}$. kovo - balandžio mėnesiais. Gauti duomenys apdoroti SPSS programa (22 versija). Populiaciją sudare Klaipèdos ligoninèse intensyvios terapijos ir chirurgijos skyriuose dirbantys slaugytojai. Pateikti 78 klausimynai, analizei atrinkti teisingai užpildyti 69 klausimynai. Imties dydis 69 , atsako dažnis $-88,46 \%$. Tyrime dalyvavo įvairių amžiaus grupių slaugytojai. Daugiausia respondentų buvo $41-50$ metų amžiaus. Pagal darbo stažą dauguma slaugytojų buvo turintys 20 - 29 metų stažą ir ịgiję aukštesniji išsilavinimą.

Klausimyną sudare dvi dalys: bendroji (demografinè) ir specialioji. Bendroji dalis skirta duomenims apie respondentus, ji apima klausimus, susijusius su amžiumi, lytimi, darbo stažu, darbo vieta ir išsilavinimu. Šią dalị sudaro 5 uždaro tipo klausimai, sukurti autorès Raimondos Jonikaitès. Specialiąją dalį sudaro 16 uždaro tipo klausimų. Pasitenkinimo gyvenimu klausimyno trumpoji forma (angl. Quality of Life Enjoyment and Satisfaction Questionnaire - Short Form (Q-LES-QSF)) yra sukurta iš originalios ilgosios formos (angl. Quality of Life Enjoyment and Satisfaction Questionnaire) ir visiškai atitinka jos koncepciją. Klausimynas sukurtas Jungtinèse Amerikos Valstijose J. Endicott'o (1993), šis tyrimo instrumentas pasirinktas todèl, kad yra trumpas ir aiškiai suprantamas respondentui. Pasitenkinimo gyvenimu klausimynas įvertina fizinę būklę, subjektyvius jausmus, laisvalaikį, socialinius ryšius, pasitenkinimą gyvenimu [25]. Remiantis moksline literatūra jis papildytas 2 uždaro tipo klausimais, sukurtais autorès, kuriais siekiama išsiaiškinti, kokius darbo aplinkos psichologinius ir fizinius rizikos veiksnius patiria slaugytojos.

Pagal naudotą J. Endicott'o (1993) tyrimo instrumentą pasitenkinimas gyvenimu yra apskaičiuojamas sumuojant pirmu 14 klausimų taškus, o paskutiniai klausimai vertinami atskirai. Galimų taškų suma yra nuo 14 iki 70. Galima minimali taškų suma yra 14, galima maksimali suma yra 70. Rezultatą galima išreikšti procentais nuo maksimalios sumos. Taigi formulę galima išreikšti (surinkta taškų suma - 14)/56 [10]. Vertinant pasitenkinimo gyvenimu klausimyno pagalba fiksuotu ịverčiu vidinị suderinamumą, naudotas Cronbach $\alpha$ koeficientas. Koeficiento reikšmès iki 0,6 rodo žemą skalès patikimumą, 0,6 - 0,7 - pakankamą, $0,7-1,0$ rodo aukštą vidinị skalès patikimumą [22]. Gautas slaugytojų pasitenkinimo gyvenimu rodiklių vidinis suderinamumas Kronbach'o a lygus 0,932.
1 lentelè. Darbo aplinkos psichologinių rizikos veiksnių rodiklių palyginimas

$p$-reikšme, statistinis reikšmingumo lygmuo. Skirtumai statistiškai reikšmingi, * kai $p<0,05, * *$ kai $p<0,01, * * *$ kai $p<0,001$. Rodikliu palyginimas pagal $\chi^{2}$ kriteriju.

\begin{tabular}{|c|c|c|c|}
\hline $\begin{array}{l}\text { Darbo aplinkos } \\
\text { psichologiniai } \\
\text { rizikos veiksniai }\end{array}$ & N (Proc.) & $\chi^{2}$ & p-reikšmė \\
\hline Intensyvus darbas & 57 (46,3 proc.) & \multirow{5}{*}{52,818} & \multirow{5}{*}{$0,000 * * *$} \\
\hline $\begin{array}{l}\text { Organizaciniai dar- } \\
\text { bo trūkumai }\end{array}$ & 11 (8,9 proc.) & & \\
\hline $\begin{array}{l}\text { Kolegu psichologi- } \\
\text { nis smurtas }\end{array}$ & 15 (12,2 proc.) & & \\
\hline $\begin{array}{l}\text { Pacientu psicholo- } \\
\text { ginis smurtas }\end{array}$ & 25 (20,3 proc.) & & \\
\hline $\begin{array}{l}\text { Darbo pareigu stre- } \\
\text { soriai }\end{array}$ & 15 (12,2 proc.) & & \\
\hline
\end{tabular}

Statistinė kiekybinių duomenų analizė atlikta naudojant SPSS programą (22 versija). Statistinès duomenų analizès rezultatai pateikiami paveiksluose ir lentelèse, kurie parengti Microsoft Office EXEL programa. Duomenų atitikimo normaliajam skirstiniui ịvertinimui naudojamas Shapiro-Wilk testas, skaičiuojami asimetrijos ir eksceso koeficientai. Skalių vidiniam suderinamumui nustatyti skaičiuojami Kronbach'o $\alpha$ koeficientai. Statistinei duomenų analizei taikyti šie metodai: dviejų ar didesnių imčių palyginimui $\chi^{2}$ kriterijus, dviejų nepriklausomų imčių lyginimui naudojamas t-Stjudent'o kriterijus, statistiniams ryšiams tarp požymiu nustatyti skaičiuojamas Pearson'o koreliacijos koeficientas. Pateikiant rezultatus nurodomas statistinis reikšmingumas: $\mathrm{p}<0,05, \mathrm{p}<0,01, \mathrm{p}<0,001-$ statistiškai reikšmingas skirtumas, $\mathrm{p}>0,05, \mathrm{p}>0,01, \mathrm{p}>$ 0,001 - statistiškai nereikšmingas skirtumas.

Siekiant patikrinti, ar duomenys yra pasiskirstę pagal normalujj skirstini, buvo atliekamas Shapiro-Wilk testas, skaičiuojami asimetrijos ir eksceso koeficientai. Pagal Shapiro-Wilk testą slaugytojų pasitenkinimo gyvenimu rodikliai atitinka normalujji skirstini ( $\mathrm{W}=0,975, \mathrm{p}>0,05)$. Be to, ivvertinus duomenų asimetrijos, eksceso koeficientus bei jų standartines paklaidas (visų duomenų $\mathrm{SA}=0,289$ ir $\mathrm{SE}=0,570$ ), paaiškèjo, kad rodikliai atitinka normaluji skirstinị (rodikliai tenkina sąlygą 3SA $>\mathrm{A}$ ir $3 \mathrm{SE}>\mathrm{E}$ ).

Tyrimo instrumentas patvirtintas KU SvMF slaugos katedros Etikos komisijos posèdyje. Prieš apklausą leidimas atlikti tyrimą gautas iš ligoninių administracijų. Pasitenkinimo gyvenimu klausimynas yra viešai paskelbtas ir gali būti naudojamas be atskiro leidimo.

\section{Rezultatai}

Vertinant respondentų nuomonę apie patiriamus darbo 
aplinkos psichologinius rizikos veiksnius nustatyta, kad 91,3 proc. patiria vienokius ar kitokius psichologinius rizikos veiksnius. Siekiant palyginti psichologinius rizikos veiksnius, naudojamas $\chi^{2}$ kriterijus. Psichologinių veiksnių dažnumas, kuriuos patiria slaugytojai, reikšmingai skiriasi $\left(\chi^{2}=52,818, p<0,001\right)(1$ lentelè). Psichologiniai veiksk niai pagal svarbą pasiskirste taip: intensyvus darbas (46,3 proc.), pacientu psichologinis smurtas (20,3 proc.), kolegu psichologinis smurtas (12,2 proc.), darbo pareigu stresoriai (12,2 proc.) ir organizaciniai darbo trūkumai ( 8,9 proc.).

Vertinant respondentų nuomonę apie patiriamus darbo aplinkos fizinius rizikos veiksnius, nustatyta, kad 98,6 proc. jautè vienokius ar kitokius fizinius rizikos veiksnius. Siekiant palyginti fizinius rizikos veiksnius, naudotas $\chi^{2}$ kriterijus. Fizinių rizikos veiksnių dažnumas, kuriuos patiria slaugytojai, reikšmingai skiriasi $\left(\chi^{2}=74,342, \mathrm{p}<0,001\right)(2$ lentelè). Fiziniai rizikos veiksniai pagal svarbą pasiskirste taip: pacientus kelti rankomis tenka 33,9 proc. slaugytojų, kintantị darbo laiką pažymėjo 27,4 proc., ergonominius rizikos veiksnius 21,4 proc., mikrotraumas 17,3 proc.

Respondentų pasiskirstymas pagal pasitenkinimą gyvenimu (3 lentelè), pagal tokius teiginius, kaip fizinè sveikata, nuotaika, darbas, visuomeniniai ir šeiminiai ryšiai, aktyvumas kasdieniniame gyvenime, seksualinis potraukis, sugebẻjimas judèti nejaučiant svaigimo, lūkesčiai darbe, hobio ar laisvalaikio užsièmimai, bendrą gerovès pojūtį, daugiau kaip puse visų respondentų įvertino „gerai“ arba „labai gerai“. Iš kitų išsiskiria savo finansinès situacijos vertinimas - daugiau kaip penktadalis respondentų ją apibūdina kaip blogą ir labai blogą. Nepaisant to, savo susikurtas gyvenimo sąlygas, laisvalaikị, namų ūkị respondentai vertina geriau: gyvenimo sąlygas ir laisvalaikị "blogai" vertina tik apie 6 proc., o namų ūki -3 proc. respondentų. Vertindami savo bendrą pasitenkinimą gyvenimu per

2 lentelè. Darbo aplinkos fizinių rizikos veiksnių rodiklių palyginimas

$p$-reikšme , statistinis reikšmingumo lygmuo. Skirtumai statistiškai reikšmingi, * kai $p<0,05, * *$ kai $p<0,01, * * *$ kai $p<0,001$. Rodikliu palyginimas pagal $\chi^{2}$ kriteriju.

\begin{tabular}{|l|c|c|c|}
\hline $\begin{array}{l}\text { Darbo aplinkos } \\
\text { fiziniai rizikos } \\
\text { veiksniai }\end{array}$ & N (Proc.) & \multirow{2}{*}{$\chi^{\mathbf{2}}$} & p-reikšmė \\
\hline $\begin{array}{l}\text { Ergonominiai rizi- } \\
\text { kos veiksniai }\end{array}$ & $36(21,4$ proc. $)$ & & \\
\cline { 1 - 2 } $\begin{array}{l}\text { Pacientų kėlimas } \\
\text { rankomis }\end{array}$ & $57(33,9$ proc. $)$ & \multirow{2}{*}{74,342} & $0,000^{* * *}$ \\
\cline { 1 - 2 } Mikrotraumos & $29(17,3$ proc. $)$ & & \\
\cline { 1 - 2 } $\begin{array}{l}\text { Kintantis darbo } \\
\text { laikas }\end{array}$ & $46(27,4$ proc. $)$ & & \\
\hline
\end{tabular}

praejusią savaitę, daugiau kaip pusè visų respondentų (60,9 proc.) pasitenkinimą gyvenimu ịvertino „gerai“, „labai gerai“ vertino tik 8,7 proc. Slaugytojų pasitenkinimas gyvenimu buvo vertintas susumavus klausimyne pateiktu 14 teiginių ivvertinimus (3 lentelè). Naudojant J. Endicott'o (1993) skaičiavimo metodiką nustatyta, kad slaugytojos savo pasitenkinimą gyvenimu ịvertino geriau nei vidutiniškai, vertinimo vidurkis buvo 66,8 proc.

Vertinant slaugytojų darbo aplinkos rizikos veiksnių ir jų pasitenkinimo gyvenimu sąsajas nustatyta, kad statistiškai reikšmingas atvirkštinis ryšys tarp pacientų kèlimo rankomis ir slaugytojų pasitenkinimo gyvenimu ( $\mathrm{r}=-0,256$, $\mathrm{p}<0,05)$. Kuo slaugytojai dažniau kelia pacientus, tuo jų pasitenkinimas gyvenimu yra prastesnis (4 lentelè).

\section{Rezultatų aptarimas}

Šio tyrimo rezultatai rodo, kad svarbiausias slaugytojų darbo aplinkos psichologinis rizikos veiksnys yra intensyvus darbas (46,3 proc.). Slaugytojų darbo krūvis pastaraisiais metais vis didejja visame pasaulyje, nes sunkèjant pacientų sveikatos būklei ir didẻjant pacientų kaitai slaugytojams tenka vykdyti labai sudètingą slaugos procesą [3]. Tyrèjai taip pat teigia, kad medicinos personalas dažniau nei kitų profesinių grupių darbuotojai yra veikiami per didelio darbo krūvio [19].

Analizuojant darbo aplinkos psichologinius rizikos veiksnius nustatyta, kad pacientu psichologini smurta patiria 20,3 proc. slaugytojų, o iš kolegu - 12,2 proc. slaugytojų. Smurtas darbo vietoje yra rimta pasaulinio masto problema, kuriai pastaruoju metu yra skiriama daug demesio mokslinèse publikacijose. Remiantis mokslininkų atliktais tyrimo duomenimis paaiškejjo, jog net 22 proc. slaugytojų dažnai patiria smurtą iš pacientų. Tyrimo rezultatai parodè, kad smurtas, patirtas iš pacientų ir jų artimujų, yra svarbi priežastis atsisakyti slaugytojo profesijos [11]. Kauno apskrities gydymo ịstaigose atlikto tyrimo metu mokslininkai nustatè, kad slaugytojos, patiriančios negatyvų elgesi darbe, skundžiasi pablogejusia sveikata, patiria stresą, mažėja jų pasitenkinimas darbu [27].

Atlikus tyrimą nustatyta, jog darbo pareigų stresorius patiria 12,2 proc. slaugytojų. Didesni stresą slaugytojams sukelia menka kvalifikacija, profesinių žinių stygius [14].

Šio tyrimo rezultatai parodè, jog organizacinius darbo trūkumus jaučia beveik dešimtadalis ( 8,9 proc.) slaugytojų. Dažnai slaugytojai atlieka užduotis, kurias galètų atlikti mažiau kvalifikuotas personalas. Slaugytojai nuolat atlieka darbus, nesusijusius su klinikinemis funkcijomis, tokius kaip pacientų transportavimas, padèklų su maistu nešiojimas, lovų tvarkymas. Tai vyksta dažnai, nes taupydamos ligoninès atsisake pagalbinio personalo, kuris turètų at- 
3 lentelè. Respondentų pasiskirstymas pagal pasitenkinimo gyvenimu teiginių vertinimą $n$-atveju skaičius.

\begin{tabular}{|c|c|c|c|c|c|}
\hline $\begin{array}{l}\text { Viską apibendrinus, kiek per praèju- } \\
\text { sią savaitę buvote patenkinta (-as)... }\end{array}$ & $\begin{array}{l}\text { Labai blogai } \\
\text { n (\%) }\end{array}$ & $\begin{array}{l}\text { Blogai } \\
\text { n (\%) }\end{array}$ & $\begin{array}{l}\text { Vidutiniškai } \\
\text { n (\%) }\end{array}$ & $\begin{array}{l}\text { Gerai } \\
\text { n (\%) }\end{array}$ & $\begin{array}{l}\text { Labai gerai } \\
\text { n (\%) }\end{array}$ \\
\hline ...fizine sveikata? & $3(4,3)$ & $4(5,8)$ & $25(36,2)$ & $29(42,1)$ & $8(11,6)$ \\
\hline ...nuotaika? & $3(4,3)$ & $5(7,2)$ & $19(27,5)$ & $31(45,0)$ & $11(16,0)$ \\
\hline ...darbu? & $0(0)$ & $5(7,2)$ & $26(37,7)$ & $30(43,5)$ & $8(11,6)$ \\
\hline ...namų ūkiu? & $0(0)$ & $2(2,9)$ & $17(24,6)$ & $36(52,2)$ & $14(20,3)$ \\
\hline ...visuomeniniais ryšiais? & $0(0)$ & $4(5,8)$ & $15(21,8)$ & $43(62,3)$ & $7(10,1)$ \\
\hline ...šeiminiais ryšiais? & $0(0)$ & $1(1,4)$ & $12(17,4)$ & $32(46,4)$ & $24(34,8)$ \\
\hline ...laisvalaikiu? & $1(1,4)$ & $4(5,8)$ & $22(31,9)$ & $28(40,6)$ & $14(20,3)$ \\
\hline ...aktyvumu kasdieniniame gyvenime? & $0(0)$ & $6(8,7)$ & $18(26,1)$ & $37(53,6)$ & $8(11,6)$ \\
\hline $\begin{array}{l}\text {...seksualiniu potraukiu ir/arba poten- } \\
\text { cija? }\end{array}$ & $1(1,4)$ & $5(7,2)$ & $20(28,9)$ & $31(45,0)$ & $12(17,4)$ \\
\hline ...finansine situacija? & $1(1,4)$ & $14(20,3)$ & $29(42,0)$ & $25(36,4)$ & $0(0)$ \\
\hline ...gyvenimo sąlygomis? & $0(0)$ & $4(5,8)$ & $26(37,7)$ & $29(42,0)$ & $10(14,5)$ \\
\hline $\begin{array}{l}\text {...sugebèjimu judèti nejaučiant svaigi- } \\
\text { mo, nestabilumo? }\end{array}$ & $0(0)$ & $3(4,3)$ & $18(26,0)$ & $34(49,3)$ & $14(20,3)$ \\
\hline $\begin{array}{l}\text {...savo lūkesčiais darbe, hobio ar laisva- } \\
\text { laikio užsièmimais? }\end{array}$ & $0(0)$ & $6(8,7)$ & $23(33,3)$ & $36(52,2)$ & $4(5,8)$ \\
\hline ...bendru gerovės pojūčiu? & $0(0)$ & $6(8,7)$ & $22(31,9)$ & $37(53,6)$ & $4(5,8)$ \\
\hline $\begin{array}{l}\text {...vartojamais vaistais? (jei nevartojate, } \\
\text { pažymékite čia } 44(63,8) \text { ir nežymékite } \\
\text { skaičiaus). }\end{array}$ & $0(0)$ & $5(7,2)$ & $11(16,0)$ & $8(11,6)$ & $1(1,4)$ \\
\hline $\begin{array}{l}\text { Kaip įvertintumėte bendrą pasitenkini- } \\
\text { mą gyvenimu per praejjusią savaitę? }\end{array}$ & $0(0)$ & $3(4,3)$ & $18(26,1)$ & $42(60,9)$ & $6(8,7)$ \\
\hline
\end{tabular}

likti tokius darbus. Darbas, kuris buvo anksčiau atliekamas pagalbinių darbuotojų, dažnai yra atliekamas slaugytojų ir šios pareigos tampa slaugytojų darbo dalimi [9].

Remiantis šio tyrimo rezultatais, svarbiausias slaugytojų darbo aplinkos fizinis rizikos veiksnys yra pacientu kèlimas rankomis (33,9 proc.). Mokslininkai nustate, kad slaugytojų, kurios skundèsi skeleto ir raumenų skausmais, vienas iš dažniausiai nurodytų rizikos faktorių buvo ligonių kèlimas $(52,4 \%)$ [1].

Atlikto tyrimo rezultatai parode, kad daugiau nei ketvirtadalis $(27,4$ proc.) respondentų, kaip vieną iš darbo aplinkos rizikos veiksnių, pažymejjo kintantị darbo laiką. Tarptautine slaugymo taryba (angl. The international council of nursing) konstatuoja, kad daugelis sveikatos priežiūros įstaigų paslaugas teikia 24 valandas per parą, todèl pamaininis darbas yra būtinybė [8]. Tyrejjai taip pat labai susirūpinę, kad toks darbas gali turèti neigiamą įtaką sveikatai, individo produktyvumui [8]. A. Liumienè (2013) [20] atliko tyrimą, kurio tikslas - nustatyti slaugos specialistų darbo laiko režimo ir sveikatos sąsajas. Tyrimo metu nustatytos pagrindinės slaugytojų fizinès sveikatos problemos, pasireiškiančios fiziniu nuovargiu, stuburo skausmu, galvos svaigimu ir skausmu, apetito pokyčiais. Tyrimo da-
4 lentelè. Slaugytojų darbo aplinkos rizikos veiksnių ir jų pasitenkinimo gyvenimu sąsajos $r$-Pearson'o koreliacijos koeficientas

\begin{tabular}{|c|c|c|}
\hline \multicolumn{2}{|c|}{ Darbo aplinkos rizikos veiksniai } & \multirow{2}{*}{$\begin{array}{l}\text { Pasitenkini- } \\
\text { mas gyvenimu } \\
\mathrm{r}=-0,125 \\
\mathrm{p}=0,304\end{array}$} \\
\hline \multirow{5}{*}{$\begin{array}{l}\text { Darbo } \\
\text { aplin- } \\
\text { kos } \\
\text { psicho- } \\
\text { loginiai } \\
\text { veiks- } \\
\text { niai }\end{array}$} & Intensyvus darbas & \\
\hline & Organizaciniai darbo trūkumai & $\begin{array}{l}r=-0,056 \\
p=0,647\end{array}$ \\
\hline & Kolegų psichologinis smurtas & $\begin{array}{l}r=-0,034 \\
p=0,781\end{array}$ \\
\hline & Pacientų psichologinis smurtas & $\begin{array}{l}r=0,017 \\
p=0,889\end{array}$ \\
\hline & Darbo pareigų stresoriai & $\begin{array}{l}r=-0,094 \\
p=0,443\end{array}$ \\
\hline \multirow{4}{*}{$\begin{array}{l}\text { Darbo } \\
\text { aplikos } \\
\text { fiziniai } \\
\text { veiks- } \\
\text { niai }\end{array}$} & Ergonominiai rizikos veiksniai & $\begin{array}{l}\mathrm{r}=0,085 \\
\mathrm{p}=0,489\end{array}$ \\
\hline & Pacientų kèlimas rankomis & $\begin{array}{l}\mathrm{r}=-0,256 \\
\mathrm{p}=0,034^{*}\end{array}$ \\
\hline & Mikrotraumos & $\begin{array}{l}r=-0,001 \\
p=0,997\end{array}$ \\
\hline & Kintantis darbo laikas & $\begin{array}{l}r=0,025 \\
p=0,839\end{array}$ \\
\hline
\end{tabular}


lyviai skundèsi, kad atsirado nuotaikų kaita, abejingumas, dirglumas ir ittampa, suvokimo, atminties pokyčiai. Dèl kintančio darbo režimo kyla problemų planuojant savo ir šeimos laisvalaikị bei bendraujant su artimaisiais [20].

Šio tyrimo rezultatai parode, kad ergonominius rizikos veiksnius patiria 21,4 proc. slaugytojų. Mokslininkai, atlikę tyrimą, nustate, kad slaugytojos darbe jaučia ergonominius rizikos veiksnius dirbant ilgai nekeičiant kūno padèties, pasilenkus, atsitūpus, stovint [1].

Vertinat darbo aplinkos fizinius rizikos veiksnius, nustatyta, kad mikrotraumas patyre 17,3 proc. slaugytojų. Panašūs rezultatai gauti JAV atliktame tyrime, kurio tikslas buvo ištirti ryšį tarp darbo sąlygų ir susižalojimo adatomis. Ištyrus slaugytojas paaiškejjo, kad mikrotraumas patyre 16,3 \% slaugytojų. Rizika patirti tokius sužalojimus buvo susijusi su per dieną sunaudojamų adatų kiekiu, darbo dienos trukme, darbu savaitgaliais, darbu ne dienos pamainoje [26].

Šio tyrimo metu nustatyta, kad slaugytojai pasitenkinimą gyvenimu ịvertino geriau nei vidutiniškai (vertinimo vidurkis buvo 66,8 proc. balų iš 100 proc. maksimaliai galimų). Panašius tyrimo rezultatus tyrèjai gavo ịvertinę Šiaulių krašto slaugytojų pasitenkinimą gyvenimu. Apie pusė (42 proc.) tyrime dalyvavusių slaugytojų yra patenkintos gyvenimu [17].

Tyrimo metu nustatyta reikšmingas atvirkštinis ryšys tarp vieno iš darbo aplinkos fizinių rizikos veiksnių, t.y. pacientų kèlimo rankomis bei slaugytojų pasitenkinimo gyvenimu $(r=-0,256, p<0,05)$. Nustatytas statistiškai reikšmingas atvirkštinis ryšys tarp pacientų kèlimo rankomis ir slaugytojų pasitenkinimo gyvenimu pagrindžia neigiamą poveiki slaugytojų pasitenkinimui gyvenimu. Palankios darbo sąlygos, gera slaugytojų fizinè ir psichologinè savijauta darbe sumažintų personalo kaitą, sutaupytų lèšų ìstaigai. Naudą patirtų ir slaugos paslaugų vartotojai, nes juos slaugytų fiziškai stiprūs ir psichologiškai stabilūs specialistai. Pasitenkinimas gyvenimu ir darbu yra subjektyvios ir tarpusavyje persipynusios sąvokos, juos lemia ne tik darbiniai faktoriai, bet ir žmogaus požiūris, jo asmenybė, psichologinè būklè, gyvenamoji aplinka, šeiminè padètis, santykiai šeimoje ir kiti faktoriai, ị kurių itaką šiame darbe neatsižvelgta.

\section{Išvados}

1. Dažniausiai slaugytojų nurodomi darbo aplinkos rizikos veiksniai yra intensyvus darbas $(46,3$ proc.) ir pacientų kèlimas rankomis (33,9 proc.).

2. Slaugytojai savo pasitenkinimą gyvenimu ịvertino geriau nei vidutiniškai. Vertinimo vidurkis $-66,8$ proc. balu iš 100 proc. maksimaliai galimų.
3. Tarp pacientų kèlimo rankomis ir slaugytojų pasitenkinimo gyvenimu nustatytas statistiškai reikšmingas atvirkštinis ryšys: slaugytojų, kuriems dažniau tenka kelti pacientus rankomis, pasitenkinimas gyvenimu yra prastesnis.

\section{Literatūra}

1. Anap DB, Iyer C, Rao K. Work related musculoskeletal disorders among hospital nurses in rural Maharashtra, India: amulti centre survey. International Journal of Research in Medical Sciences 2013;1(2):101-107. http://dx.doi.org/10.5455/2320-6012.ijrms20130513

2. Bakker BA, Hakanen JJ, Demerouti E, Xanthopoulou D. Job resources boost work engagement, particularly when job demands are high. Journal of Educational Psychology 2007;99(2):274-284.

http://dx.doi.org/10.1037/0022-0663.99.2.274

3. Blaževičienè A., Riklikienė O. Slaugos specialistų darbo jègos kaitos tendencijos Lietuvoje. Sveikatos mokslai, 2008;6:20122016.

4. Brooks BA, Anderson MA. Defining quality of nursing work life. Nursing Economic 2005;23(6):319-326.

5. Boonrod W. Quality of working life: Perceptions of professional nurses at phramongkutklao hospital. Journal of the Medical Association of Thailand 2009; 92(1):7-15.

6. Dargahi H, Changizi V, Gharabagh EJ. Radiology employees' quality of work life. Acta Medica Iranica 2012;50(4):250-256.

7. Daubermann DC, Tonete VLP. Quality of work life of nurses in primary healthcare. Acta Paulista de Enfermagem 2012;25(2):277-283.

http://dx.doi.org/10.1590/S0103-21002012000200019

8. Deori D. The experience of night shift registered nurses in an acute care setting: a phenomenological study. International Journal of Latest Research in Science and Technology 2012;1(2):201-204.

9. Duffeld C, Gardner G, Catling-Paull C. Nursing work and the use of nursing time. Journal of Clinical Nursing 2008;17(24):3269-3274.

http://dx.doi.org/10.1111/j.1365-2702.2008.02637.x

10. Endicott J. 1993. Quality of Life Enjoyment and Satisfaction Questionnaire - Short Form (Q-LES-SF). [žiūrèta 2015 m. sausio 10 d.] Prieiga per internetą: $<$ https://outcometracker.org/ library/Q-LES-Q-SF.pdf.>.

11. Estryn-Behar M, van der Heijden B, Camerino D, Fry C, Le Nezet O, Conway PM, Hasselhorn HM. Violence risks in nursing-results from the European, NEXT' Study. Occupational Medicine 2008;58(2):107-114.

http://dx.doi.org/10.1093/occmed/kqm142

12. Gailienė G., Cenenkienè R. Medicinos darbuotojų profesiniai biologiniai rizikos veiksniai. Medicina, 2009;45(7):530-536.

13. Gurses AP, Carayon P, Wall M. Impact of performance obstacles on intensive care nurses' workload, perceived quality and safety 
of care, and quality of working life. Health Services Research 2009;44(2):422-443.

http://dx.doi.org/10.1111/j.1475-6773.2008.00934.x

14. Healy CM, McKay MF. Nursing stress: the effects of coping strategies and job satisfaction in a sample of Australian nurses. Journal of Advanced Nursing 2000;31(3):681-688. http://dx.doi.org/10.1046/j.1365-2648.2000.01323.x

15. Istomina N., Bagdonas R., Krivickienè P., KrivickaitèMušeikè A. Slaugytojų, dirbančių intensyviosios terapijos skyriuose, gyvenimo kokybès vertinimas. Sveikatos mokslai, 2012;21(7):185-190.

16. Jovarauskaitė A., Tolutienė G. Universiteto dėstytojų pasitenkinimui darbu įtakos turintys veiksniai. Jaunųjų mokslininkų darbai, 2010;1(26):95-103.

17. Juozulynas A., Danasaitė E., Čiplienė M., Samsonienė L., Tamašauskienė E. Šiaulių regiono slaugytojų gyvenimo kokybės įvertinimas. Sveikatos mokslai, 2007;1:659-662.

18. Kaliatkaitė J., Pajarskienė B. Restruktūrizuojamose Lietuvos ligoninėse dirbančių slaugytojų subjektyvi sveikata. Visuomenès sveikata. Priedas, 2013;1:36-42.

19. Lin CM, Li CY. Prevalence of cardiovascular risk factors in Taiwanese healthcare workers. Ind Health 2009;47(4):411-418. http://dx.doi.org/10.2486/indhealth.47.411

20. Liumienè A. Sveikatos ir kintančio darbo laiko režimo sąsajos: slaugos kontekstas. Studijos šiuolaikinèje visuomenèje, 2013; 4(1):184-190.

21. Mohammadi A, Sarhanggi F, Ebadi A, Daneshmandi M, Reiisifar A, Amiri F, Hajamini Z. Relationship between psychological problems and quality of work life of Intensive Care Units Nurses. Iranian Journal of Critical Care Nursing 2011;4,(3):135-140.

22. Pukėnas K. Kokybinių duonemų analizė SPSS programa. Kaunas: Lietuvos kūno kultūros akademija, 2011.

23. Santorek-Strumiłło E, Zawilska JB, Misiak P, Jabłoński S, Kordiak J, Brocki M. Influence of the shift work on circadianrhythms compare survey on health service employees and policemen. Przegl Lek. 2012;69(3):103-106.

24. Sanz-Vergel AI, Rodrkguez-Muńoz A. The spillover and crossover of daily work enjoyment and well-being: A diary study among working couples. Journal of Work and Organizational Psychology 2013;29(3):179-185.

http://dx.doi.org/10.5093/tr2013a24
25. Stevanovic D. Quality of life enjoyment and satisfaction questionnaire - short form for quality of life assessments in clinical practice: a psychometric study. Journal of Psychiatric and Mental Health Nursing 2011;18(8):744-750.

http://dx.doi.org/10.1111/j.1365-2850.2011.01735.x

26. Trinkoff AM, Le R, Geiger-Brown J, Lipscomb J. Work schedule, needle use, and needlestick injuries among registered nurses. Infection Control and Hospital Epidemiology 2007;28(2):156-164.

http://dx.doi.org/10.1086/510785

27. Vasilavičius P., Januškevičius V., Ustinavičienė R., Vainauskas S., Šidagytė R. Kauno apskrities gydymo ịstaigų slaugytojų patiriamo negatyvaus elgesio sąsajos su sveikatos sutrikimais. Visuomenès sveikata, 2010;1(48):59-66.

28. Wallace JE, Lemaire JB, Ghali WA. Physician wellness: a missing quality indicator. Lancet 2009;374(9702):1714-1721. http://dx.doi.org/10.1016/S0140-6736(09)61424-0

\section{WORK ENVIRONMENTAL FACTORS IMPACT ON LIFE SATISFACTION OF NURSES \\ R. Jonikaitè, I. Brasaitė}

Key words: nurse, life satisfaction, work environmental risk factors.

Summary

Nurses in their work are exposed to the factors that affect their health, working capacity and physical state: high physical workload, night shifts, psychological violence, organizational drawbacks, job duties stressors. Life and work satisfaction depends on these factors and influences quality of care, patient safety, employee retention and their commitment to the organization and the profession.

The sample size consisted of 69 intensive care and surgical department nurses working in Klaipeda hospitals. The quantitative study was conducted in accordance with ethical principles. Life satisfaction questionnaire - short form was used in the survey. The data were processed with SPSS program (version 22).

The results showed that intensive work and manual patient lifting are the most common nurse work environment risk factors. Nurses rated their satisfaction with life better than average (66.8 percent). The results showed that nurses who often have to lift patients manually are less satisfied with life.

Correspondence to: raimajoni@gmail.com

Gauta 2016-10-10 